\title{
Incidence of Pod Integrity on the Fungal Microflora and Ochratoxin-A Production in Cocoa
}

\author{
Pauline Mounjouenpou (Corresponding author) \\ Institute of Agricultural Research for Development (IRAD) \\ Food technology laboratory \\ PO box 2067, Yaounde, Cameroon \\ Tel: 237-99-82-4504Ｅ-mail: mounjouenpou@yahoo.fr \\ Dominique Gueule \\ CIRAD, UPR Qualité Produits Pérennes \\ TA80/16, 34398 Montpellier Cedex 5, France
}

Suzanne Abeline Maboune Tetmoun

Institute of Agricultural Research for Development (IRAD)

Food technology laboratory

PO box 2067, Yaounde, Cameroon

E-mail: abmbesso@yahoo.fr

\author{
Bernard Guyot \\ CIRAD, UPR Qualité Produits Pérennes \\ TA80/16, 34398 Montpellier Cedex 5, France
}

Angélique Fontana-Tachon

Université Montpellier II

UMR-IR2B (Agro-M/INRA/UM2), Place Eugène Bataillon

34095 Cedex 5, France 


\author{
Joseph Pierre Guiraud \\ Université Montpellier II \\ UMR-IR2B (Agro-M/INRA/UM2), Place Eugène Bataillon \\ 34095 Cedex 5, France
}

Received: June 8, 2012 Accepted: June 22, 2012

doi:10.5296/jbls.v3i1.2231 URL: http://dx.doi.org/10.5296/jbls.v3i1.2231

\begin{abstract}
Ochratoxin-A (OTA) is a mycotoxin that has nephrotoxic, tetragenic, immunotoxic and carcinogenic effects in the human organism. It contaminates several foodstuffs, notably cocoa. The purpose of our study was to compare the incidence of cocoa pod integrity on the fungal microflora and ochratoxin- A production in Cameroon. Irrespective of pod condition, fermented cocoa beans were contaminated by OTA. The maximum mould content was obtained in beans from damaged pod. However, the fungal microflora was more diversified for beans from pod damaged during harvesting than for beans from intact pods, throughout the post-harvest process. The toxigenic strains isolated belonged to the genera Aspergillus. Aspergillus carbonarius isolated from damaged pods, displayed the greatest OTA production which was $110.7 \mathrm{ng} \cdot \mathrm{g}^{-1}$ on cocoa medium and $2772,0 \mathrm{ng} \cdot \mathrm{g}^{-1}$ on official medium. There was a good correlation between OTA presence in the beans and isolated toxigenic strains.
\end{abstract}

Keywords: Cocoa, fungal microflora, ochratoxin A, A. carbonarius.

\title{
1. Introduction
}

Ochratoxin A (OTA) is a toxic secondary metabolite produced by several species of Aspergillus and Penicillium genera. OTA is mainly produced by Aspergillus carbonarius, A. niger and A. ochraceus in tropical zones, and by Penicillium verrucosum and $P$. nordicum in temperate zones (Pitt et al., 2000; Abrunhosa et al., 2001; O'Callaghan et al., 2003).

OTA attracts particular attention due to the damage it causes in the human and animal organism (Abarca et al., 1998). It has nephrotoxic (Mantle and McHugh, 1993), immunotoxic, teratogenic and carcinogenic (Kuiper-Goodman and Scott, 1989; Kuiper-Goodman, 1996; Höhler, 1998) effects in human and animal organisms.

OTA contaminates several foodstuffs and drinks, notably cocoa (Pittet et al., 1996; Blanc et al., 1998; Hurst and Martin, 1998, Jorgensen, 1998; Skaug, 1999; Gareis and Scheuer, 2000; Thirumala-Devi et al., 2001; WHO, 2001).

Fermentation is the main stage in cocoa post-harvest processing. It is generally carried out in 
a traditional manner under the action of natural microorganisms. Many studies have been carried out on the influence of post-harvest processing on OTA contamination in coffee (Suàrez-Quiroz et al., 2005, Durand, 2009; Duris et al., 2010) and cocoa (Mounjouenpou et al., 2011).

The purpose of our study was to compare the incidence of cocoa pod integrity on the fungal microflora and Ochratoxin- A production in Cameroon.

\section{Material and Methods}

\subsection{Cocoa Post-harvest Treatments}

Heap fermentation of cocoa pods (Theobroma cacao L.) from the Kumba region of Cameroon was done either immediately after harvesting in the field with undamaged or damaged pods, or 10 days later with damaged pods. Fermentation was carried out in each case during 5 days, and using $50 \mathrm{~kg}$ of beans. In doing heap fermentation, the beans were tipped into banana leaves placed on the ground. The heap was then covered with other banana leaves. Natural drying (in the sun) was carried out for between 5 and 10 days. Cocoa samples were taken at different stages of processing. This involved unfermented beans and fermented sun-dried beans.

\subsection{Microbiological Analyses}

The inoculum was obtained by soaking 15 cocoa beans in $90 \mathrm{ml}$ of a peptone water solution $(0.1 \% \mathrm{w} / \mathrm{v})$ for $10 \mathrm{~min}$ (Hocking, 1991). The surface of PDA medium was inoculated and the dishes were incubated at $25^{\circ} \mathrm{C}$ for 5 to 7 days. Isolated moulds were set apart according to the identification key for common food-borne fungi (Samson et al., 1995). The identification of Aspergillus and Penicillium moulds was confirmed using molecular techniques by the Fungi and Yeasts Culture Collection at the Catholic University of Louvain in Belgium (BCCM ${ }^{\mathrm{TM}} / \mathrm{MUCL}$ Culture Collection).

\subsection{Study of OTA Production by Isolated Strains}

\subsubsection{PDA Culture Medium}

The study of OTA production in PDA culture medium was described by Sùarez-Quiroz et al. (2004). For each strain isolated, a suspension of $3 \times 10^{6}$ of conidia. $\mathrm{mL}^{-1}$ was made up by scraping a PDA culture dish with a saline solution containing $0.01 \%$ Tween 80 . Five microliters of the suspension was deposited in the centre of a dish of PDA medium which was incubated at $25^{\circ} \mathrm{C}$. After 20 days of incubation, direct extraction was carried out from 3 agar discs taken from the centre of the colony. This extraction was done in $2.5 \mathrm{~mL}$ of solvent (methanol/formic acid 25:1, v/v) for $15 \mathrm{~min}$ in an ultrasound bath.

\subsubsection{Cocoa Culture Medium}

The method used to study OTA in cocoa medium are described by Mounjouenpou et al. (2008). In short, $50 \mathrm{~g}$ of cocoa beans (verified OTA-free) were inoculated with $8 \mathrm{~mL}$ of a suspension of $50 \times 10^{6}$ conidia. $\mathrm{mL}^{-1}$ and incubated at $25^{\circ} \mathrm{C}$ for 20 days. Extraction was carried out in an acetonitrile/water solution $(60: 40 \mathrm{v} / \mathrm{v})$ for $40 \mathrm{~min}$. 


\subsection{3- Rice culture Medium (FDA method)}

The FDA method is the official method to study the capacity to produce OTA by moulds. This method is described by Tournas et al., (2001).

In all cases, OTA was quantified on extracts by HPLC with fluorimetric detection (Shimadzu LC-10 ADVP, Japan) (Nakajima et al., 1997). The operating conditions were as follows : $100 \mu \mathrm{l}$ injection loop, C18 reverse phase HPLC column, ODS $5 \mu \mathrm{m}$ with an identical pre-column thermostatically controlled at $35^{\circ} \mathrm{C}$, an isocratic flow of $1 \mathrm{ml} / \mathrm{min}$, an excitation wavelength of $333 \mathrm{~nm}$ and an emission wavelength of $460 \mathrm{~nm}$. Contents were calculated from a calibration curve established from the standard of $1 \mu \mathrm{g} \cdot \mathrm{mL}^{-1}$; ref PD $226 \mathrm{R}$. Biopharm Rhône Ltd, Glasgow, UK.

\subsection{OTA Quantification in Cocoa Beans}

The dried cocoa bean samples were frozen at $-80^{\circ} \mathrm{C}$, then ground. Fifty grams of ground beans were extracted in $200 \mathrm{ml}$ of solvent (acetonitrile/water, 60/40, v/v). Four millilitres of filtered extract were diluted in $44 \mathrm{~mL}$ of phosphate buffer. The mixture was purified on an immunoaffinity column (Ochraprep, Rhône Diagnostics, Scotland). OTA was eluted by $3 \mathrm{ml}$ of methanol and evaporated till dry in a nitrogen stream at $70^{\circ} \mathrm{C}$. The residue was resuspended in $1 \mathrm{ml}$ of the mobile phase (water/acetonitrile/acetic acid, 51:48:1, v/v). Quantification was by HPLC using the previously described method.

\section{Results}

\section{1- Fungal Microflora from Cocoa Beans}

Identification of the total fungal microflora in samples from different cocoa fermentation is given in Table 1. Independent of the type of post-harvest, cocoa beans are contaminated by moulds. This contamination is greater when the pods were damaged. The strains mainly belong to the genera Penicillium, Aspergillus, Scopulariopsis, Syncephalastrum, Mucor, Geotrichum, Trichoderma, Rhizopus, Fusarium. Figure 1 shows the phenotypic appearance of some isolated fungi. Pod integrity, and in a lesser degree, the deadline of pod - opening affected quality and quantity diversity of isolated moulds. The genus Aspergillus represents several different species which are black and correspond to the section Nigri, which contains species known to produce OTA (Aspergillus niger agg and Aspergillus carbonarius) (Amezqueta et al. 2008; Mounjouenpou et al., 2008). Wounded pods had high proliferation of A. carbonarius, Fusarium spp and A. niger in the pod openings.

Moulds were found in all types of post-harvest treatment. Their number varied depending on the sampling stage. When the pod is undamaged, the mould content of beans was not detectable before fermentation, ie less than 10 CFU.g-1. With fermentation and sun drying, the content was increased considerably to the value of $4.7 \pm 0.6 \times 10^{6} \mathrm{CFU} \cdot \mathrm{g}^{-1}$. Even when pod was damaged and beans processed immediately, mould content was still less important. The highest level of contamination was obtained with beans from damaged pods and deferred pod-opening. The content obtained was $11.7 \pm 0.9 \times 10^{6}$ CFU.g-1. After fermentation and sun drying, this content was decreased to a value of $3.7 \pm 0.5 \times 10^{6} \mathrm{CFU}_{\mathrm{g}}{ }^{-1}$. 

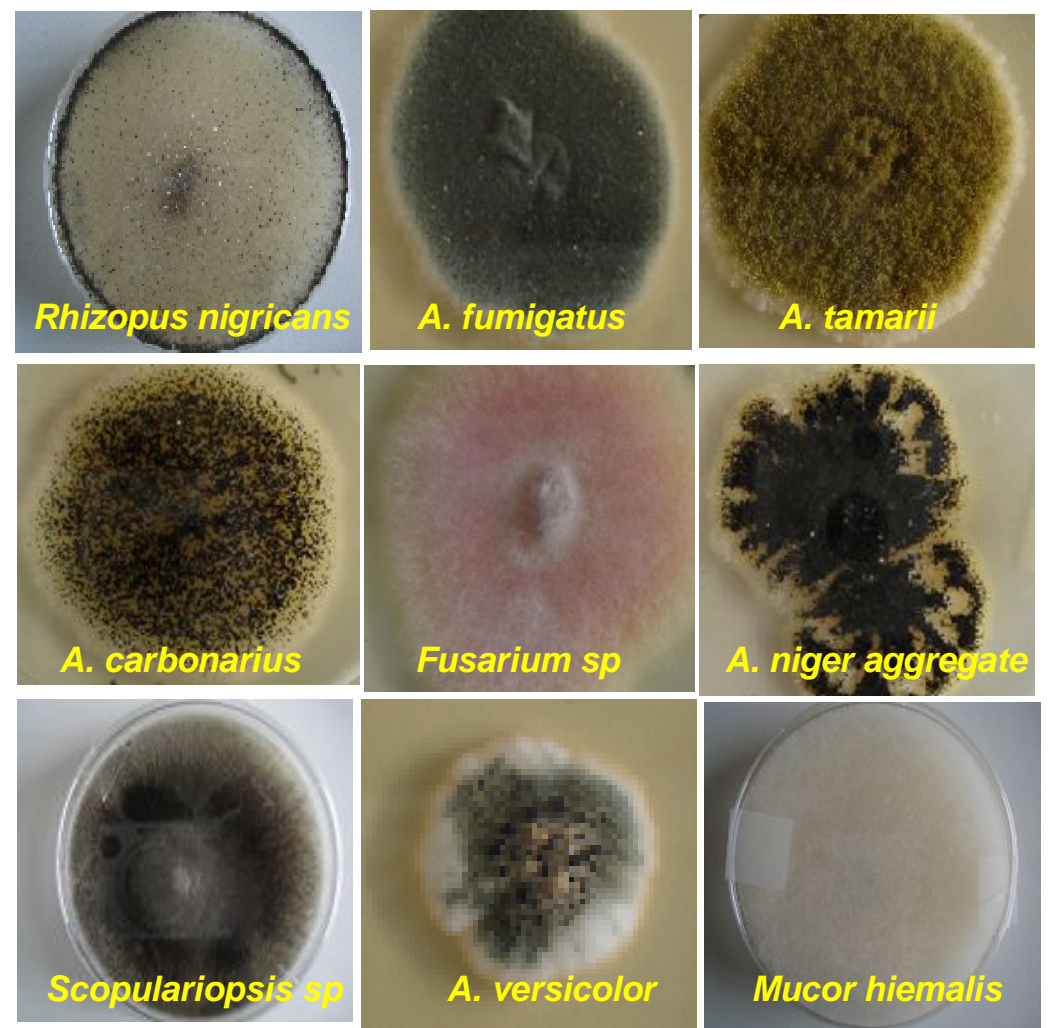

A. versicolor

Mucor hiemalis

Figure 1. Phenotypic aspect of some isolated moulds

Table 1. Identification of the total fungal microflora in samples from different cocoa fermentation

\begin{tabular}{|c|c|c|c|}
\hline $\begin{array}{l}\text { Post-harvest } \\
\text { conditions }\end{array}$ & $\begin{array}{l}\text { Sampling } \\
\text { stage }\end{array}$ & $\begin{array}{l}\text { Total } \\
\text { moulds } \\
\text { (CFU.g-1) } \\
\end{array}$ & Isolated strains \\
\hline \multirow{2}{*}{$\begin{array}{l}\text { Immediate } \\
\text { fermentation with } \\
\text { undamaged pods }\end{array}$} & $\begin{array}{l}\text { Before } \\
\text { fermentation }\end{array}$ & nd & - \\
\hline & $\begin{array}{l}\text { After } \\
\text { fermentation } \\
\text { and sun drying }\end{array}$ & $\begin{array}{l}4.7 \pm 0.6 \times \\
10^{6}\end{array}$ & $\begin{array}{l}\text { A. tamarii, A. fumigatus, Rhizopus } \\
\text { nigricans, A. niger agg }\end{array}$ \\
\hline \multirow{2}{*}{$\begin{array}{l}\text { Immediate } \\
\text { fermentation with } \\
\text { damaged pods }\end{array}$} & $\begin{array}{l}\text { Before } \\
\text { fermentation }\end{array}$ & $\begin{array}{l}0.9 \pm 0.1 \times \\
10^{6}\end{array}$ & $\begin{array}{l}\text { A. niger agg, Fusarium spp, } A . \\
\text { fumigatus, Geotrichum, }\end{array}$ \\
\hline & $\begin{array}{l}\text { After } \\
\text { fermentation } \\
\text { and sun drying }\end{array}$ & $\begin{array}{l}3.0 \pm 0.2 \times \\
10^{6}\end{array}$ & $\begin{array}{l}\text { Rhizopus nigricans, A. niger agg; } A . \\
\text { flavus, Trichoderma virens }\end{array}$ \\
\hline $\begin{array}{l}\text { Delayed } \\
\text { fermentation with }\end{array}$ & $\begin{array}{l}\text { Before } \\
\text { fermentation }\end{array}$ & $\begin{array}{l}11.7 \pm 0.9 \\
\times 10^{6}\end{array}$ & 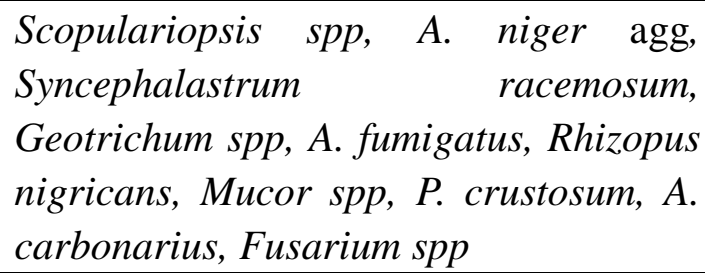 \\
\hline
\end{tabular}




\begin{tabular}{|l|l|l|l|}
\hline damaged pods & \multirow{3}{*}{$\begin{array}{l}\text { After } \\
\text { fermentation } \\
\text { and sun drying }\end{array}$} & $10^{6} \pm 0.5 \times$ & $\begin{array}{l}\text { crustosum, Prerotiorum, } \\
\text { Fusarium spp, Scopulariopsis spp, } \\
\text { Rhizopus nigricans, A. flavus, } \\
\text { Trichoderma virens, A. niger agg }\end{array}$ \\
\hline
\end{tabular}

nd: $<10$ CFU.g-1

\subsection{OTA on Cocoa and Rice Medium from Producing Moulds Isolated from Cocoa Beans}

The ability to produce OTA by isolated Aspergillus carbonarius and Aspergillus niger agg were studied using official medium (rice medium) and cocoa medium.

All strains of Aspergillus carbonarius had a high ochratoxinogenic activity which varied depending on the culture medium. OTA production was greater on rice medium with a content of 573.4 to $2772.0 \mathrm{ng} . \mathrm{g}^{-1}$ after twenty-one days of culture. On cocoa medium, values of 50.6 to $110.7 \mathrm{ng} \cdot \mathrm{g}^{-1}$ was obtained (Table 2).

Compared to Aspergillus carbonarius, strains of Aspergillus niger agg were less toxinogenic whatever the type of culture medium. OTA production ranged from undetectable $\left(<0.03 \mathrm{ng} . \mathrm{g}^{-1}\right)$ to a maximum content of $0.20 \mathrm{ng} \cdot \mathrm{g}^{-1}$ on cocoa medium. On rice culture medium, the content was from undetectable to $3.6 \mathrm{ng} \cdot \mathrm{g}^{-1}$.

Table 2. OTA production by moulds

\begin{tabular}{|l|l|l|}
\hline Strains & OTA production $\left(\mathbf{n g . g}^{-\mathbf{1}}\right)$ \\
\hline & Cocoa medium & Rice medium $($ FDA $)$ \\
\hline A. carbonarius 1 & $50.6 \pm 0.3$ & $573.4 \pm 1.6$ \\
\hline A. carbonarius 2 & $110.7 \pm 0.6$ & $2772.0 \pm 1.7$ \\
\hline A. niger 1 & nd & nd \\
\hline A. niger 2 & $0.20 \pm 0.01$ & $3.5 \pm 0.0$ \\
\hline A. niger 3 & $0.05 \pm 0.02$ & $3.6 \pm 0.0$ \\
\hline
\end{tabular}

\section{3- OTA Quantification after Cocoa Fermentation and Sun Drying}

Table 3 showed the OTA level, and toxinogenic microflora associated with cocoa beans resulting from different post harvest treatments.

When the pod was undamaged, the toxinogenic microflora associated with cocoa bean was mostly consisted of $A$. niger agg. The OTA content was in this case between nd (not detectable: $<0.03$ ng.g-1) and 0.03 ng. ${ }^{-1}$, which remained below 2 ng. $\mathrm{g}^{-1}$ (the European limit defined for cocoa beans).

When pods are damaged, a maximum level of $12.14 \mathrm{ng} \cdot \mathrm{g}^{-1}$ was observed prior to fermentation: this content was much higher than the tolerable doses. Toxigenic species associated with these beans are Aspergillus carbonarius and Aspergillus niger agg.

With fermentation and sun drying, there was a decrease of the OTA content of beans to a value of $1.01 \mathrm{ng} \cdot \mathrm{g}^{-1}$. Associated ochratoxigenic microflora was only A. niger agg. 
Table 3. OTA level on cocoa beans and associated toxigenic moulds

\begin{tabular}{|c|c|c|c|}
\hline Post-harvest conditions & Sampling stage & $\begin{array}{l}\text { Isolated } \\
\text { ochratoxigenic } \\
\text { strains }\end{array}$ & $\begin{array}{l}\text { OTA in cocoa } \\
\text { beans }\left(\mathrm{ng}^{-\mathrm{g}^{-1}}\right)\end{array}$ \\
\hline \multirow{2}{*}{$\begin{array}{l}\text { Immediate fermentation } \\
\text { with undamaged pods }\end{array}$} & Before fermentation & - & $\mathrm{nd}^{*}$ \\
\hline & $\begin{array}{l}\text { After fermentation } \\
\text { and sun drying }\end{array}$ & A. niger agg & $0.03 \pm 0.00$ \\
\hline \multirow{2}{*}{$\begin{array}{l}\text { Immediate fermentation } \\
\text { with damaged pods }\end{array}$} & Before fermentation & A. niger agg & $0.83 \pm 0.02$ \\
\hline & $\begin{array}{l}\text { After fermentation } \\
\text { and sun drying }\end{array}$ & A. niger agg & $1.33 \pm 0.03$ \\
\hline \multirow[t]{2}{*}{$\begin{array}{l}\text { Delayed fermentation with } \\
\text { damaged pods }\end{array}$} & Before fermentation & $\begin{array}{l}\text { A. niger agg, } \\
\text { A. carbonarius, }\end{array}$ & $12.14 \pm 0.10$ \\
\hline & $\begin{array}{l}\text { After fermentation } \\
\text { and sun drying }\end{array}$ & A. niger agg & $1.01 \pm 0.02$ \\
\hline
\end{tabular}

$*:<0.03$ ng. $\mathrm{g}^{-1}$

\section{Discussion}

This study was conducted in the region of Kumba in Cameroon. The climate is equatorial. It rains throughout the year and rainfall can reach $3000 \mathrm{~mm} /$ year. This rainfall implies high humidity $(\sim 90 \%)$, which promotes growth of many microorganisms that can influence the final quality of the cacao from that region.

Irrespective of pod condition and post harvest conditions, a large increase in fungal flora was found after fermentation and sun drying (qualitatively and quantitatively). The main moulds isolated in our study belonged to the genera Penicillium, Aspergillus, Mucor, Scopulariopsis, Syncephalastrum, Geotricum, Trichoderma, Rhizopus, Fusarium with some species known to produce OTA (Aspergillus niger, Aspergillus carbonarius). Similar moulds were founded by Mounjouenpou et al (2008) when studying the filamentous fungi during cocoa processing in Cameroon. Moulds belonging mainly to the species Rhizopus stolonifer (Ehrenb.) Lind., A. niger aggregate, Aspergillus flavus Link, Penicillium citrinum Thom and A. carbonarius to a minor extent were isolated from stored cocoa beans by Amezqueta et al. (2008).

Our results differed from those quoted in the literature for the fungal microflora associated with fermented beans (Maravalhas, 1966) or dried beans (Buting, 1928; Dade, 1928; Ciferri, 1931). In those publications, Aspergillus fumigatus, Aspergillus glaucus, Mucor spp and Penicillium spp were isolated.

During cocoa fermentation, there was competition between all the species present. Those with high-speed growth (Mucor, Rhizopus spp) were able to colonize first the medium before Aspergillus and Penicillium genera. Generally, drying contributed to reduce microflora. During the solar drying, sensitive species disappeared in favor to soil moulds, and more generally, environmental species. Aspergillus niger agg was found in all conditions: from fresh beans to fermented and dried beans. Contamination by Aspergillus carbonarius was mostly found in beans from the damaged pods and deferred pod - opening. This high 
contamination may come from the fact that when the pods were middle-open, cocoa beans were in direct contact with air and soil, possible source of $A$. carbonarius. When the pods are whole, strains of A. carbonarius could be less competitive to settle in the milieu. This situation would change when the pods are damaged.

Our results showed that Aspergillus carbonarius (100\% of strains) were able to produce OTA in cocoa. Strains of Aspergillus carbonarius were more toxigenic than those of A. niger agg. As in grapes (Belli et al., 2006), Aspergillus carbonarius is the main producing strain of OTA in cocoa. This coincide with that of Sage et al. (2002), Bell1' et al. (2005), Leong et al. (2006), and Astoreca et al. (2007). Despite OTA being a stable metabolite, the mycotoxin content decreased with incubation time. Other studies (Belli' et al. 2004; Esteban et al. 2006; Astoreca et al. 2007; Romero et al. 2007) have also noted this phenomenon.

Some strains of $A$. niger agg (66.6\%) were able to produce OTA in cocoa. The proportion of OTA-producing strains of $A$. niger agg varied depending on the context: Taniwaki et al. (2003) have shown that on coffee, $75 \%$ of Aspergillus ochraceus and 3\% of A. niger agg produce OTA. On cocoa, Amèzqueta et al. (2008) were found any isolated strains of A. niger agg was ochratoxinogenic. Other authors (Taniwaki et al. 1999, 2003; Sùarez-Quiroz et al. 2004; Illic et al. 2007; Leong et al. 2007) have reported that 1-9\% of Aspergillus niger strains isolated from coffee beans produce the toxin. This difference could be attributed to a natural selection in the strain or to adverse environmental conditions.

\section{References}

Abarca M. L., Bragulat M. R., Castella G., \& Cabanes F. J. (1994). Ochratoxin A production by strains of Aspergillus niger var. niger. Applied and Environmental Microbiology, 60, 2650-2652.

Abrunhosa, L., Paterson, R. R. M., Kozakiewicz, Z., Lima, N., \& Venancio, A. (2001). Mycotoxin production from fungi isolated from grapes. Letters in Applied Microbiology, 32, 240-242. http://dx.doi.org/10.1046/j.1472-765X.2001.00897.x

Amézqueta, S., González-Peñas, E., Dachoupakan, C., Murillo-Arbizu, M., López de Cerain, A., \& Guiraud J. P. (2008). OTA-producing fungi isolated from stored cocoa beans. Letters in Applied microbiology, 47, 197-201. http://dx.doi.org/10.1111/j.1472-765X.2008.02409.x

Astoreca, A., Magnoli, C., Barberis, C., Chiacchiera, S.M., Combina, M., \& Dalcero, A. (2007). Ochratoxin A production in relation to ecophysiological factors by Aspergillus section Nigri strains isolated from different substrates in Argentina. Sci Total Environ, 388, 16-23.

http://dx.doi.org/10.1016/j.scitotenv.2007.07.028

Belli, N., Bau, M., Marin, S., Abarca, M. L., Ramos, A. J., \& Bragulat, M. R. (2006). Mycobiota and ochratoxin A fungi from Spanish wine grapes. Int. J. of Food Microbiology, 111, S40-S45. http://dx.doi.org/10.1016/j.ijfoodmicro.2006.03.011

Bellı', N., Ramos, A. J., Sanchı's, V., \& Marı'n, S. (2004). Incubation time and water activity effects on ochratoxin A production by Aspergillus section Nigri strains isolated from grapes. 
Lett Appl Microbiol, 38, 72-77. http://dx.doi.org/10.1046/j.1472-765X.2003.01445.x

Bellı', N., Ramos, A.J., Coronas, I., Sanchı's, V., \& Marı'n, S. (2005). Aspergillus carbonarius growth and ochratoxin A production on a synthetic grape medium in relation to environmental factors. J Appl Microbiol, 98, 839-844.

http://dx.doi.org/10.1111/j.1365-2672.2004.02469.x

Blanc, M., Pittet, R., \& Munoz-Box, R. (1998). Behavior of ochratoxin A during green coffee roasting and soluble coffee manufacture. J. of Agri.and Food chemistry, 46, 673-675.

Buting, R. H. (1928). Fungi occurring in cocoa beans. Department of Agriculture Gold Coast year Book bull, 16, 44-62. http://dx.doi.org/10.1021/jf9707703

Ciferri, R. (1931). Studies on cocoa. Journal of the Department of Agriculture Porto Rico, 15, 223-286.

Dade, H. A. (1928). Internal moulding of prepared cocoa. Department of Agriculture Gold Coast Year Book bull, 16, 74-100.

Durand, N. (2009). Study on ochratoxin A contamination of coffee batches in the Kenyan context, in relation to cultivation methods and post harvest processing treatments. Food Add. and Contaminants.

Duris, D., Mburu, J. K. Durand, N., Clarke, R., John, M., \& Guyot, B. (2010). Ochratoxin A contamination of coffee batches from Kenya in relation to cultivation methods and post-harvest processing treatments. Food Additives and Contaminants Part A - Chemistry Analysis Control Exposure \& Risk Assessment, 27, 836-841.

Esteban, A., Abarca, M. L., Bragulat, M. R., \& Cabañes, F. J. (2006) Study of the effect of water activity and temperature on ochratoxin A production by Aspergillus carbonarius. Food Microbiol, 23, 634-640. http://dx.doi.org/10.1016/j.fm.2005.12.006

Illic, Z., Bui, T., Tran-Dinh, N., Dang, M. H. V., Kennedy, I., \& Carter, D. (2007). Survey of Vietnamese coffee beans for the presence of ochratoxigenic Aspergilli. Mycopathologia, 163, 177-182. http://dx.doi.org/10.1007/s11046-007-0099-0

Gareis, M., \& Scheuer, R. (2000). Ochratoxin A in meat and meat products. Archiv für Lebensmittelhygiene, 51, 102-104.

Hocking, A. D. (1991). Isolation and identification of xerophilic fungi in stored commodities. In fungi and Mycotoxines in Stored Products. ACIAR Proceeding ${ }^{\circ} 36$, Bangkok, Thailand. 23-26 April pp. 65-72.

Höhler, D. (1998). Ochratoxin A in food and feed: occurrence, legislation and mode of action. Zeitschrift für Ernährungswissenschaft, 37, 2-12.

Hurst, M. J., \& Martin, R. A. (1998). High-performance liquid chromatography determination of Ochratoxin A in artificially contaminated cocoa beans using automated clean-up. J. of Chromatography A, 810, 89-94. 
http://dx.doi.org/10.1016/S0021-9673(98)00202-7

Jorgensen, K. (1998). Survey of pork, poultry, coffee, beer and pulses for Ochratoxin A. Food Add. and Conta, 15, 550-554. http://dx.doi.org/10.1080/02652039809374680

Kuiper-Goodman, T. (1996). Risk assessment of ochratoxin A: an update. Food Add. and Conta., 13, 535-557.

Kuiper-Goodman, T., Scott, \& P. M. (1989). Risk assessment of the mycotoxin OchratoxinA. Biometrics Biomedical and Environmental Sciences, 2, 179-248.

Leong, S. L., Hocking, A. D., \& Scott, E. S. (2006). Effect of temperature and water activity on growth and ochratoxin A production by Australian Aspergillus carbonarius and A. niger isolates on a simulated grape juice medium. Int J Food Microbiol, 110, 209-216.

http://dx.doi.org/10.1016/j.ijfoodmicro.2006.04.005

Leong, S. L., Hien, L. T., An, T. V., Trang, N. T., Hocking, A. D., \& Scott, E. S. (2007) Ochratoxin A-producing Aspergilli in Vietnamese green coffee beans. Lett Appl Microbiol, 45, 301-307. http://dx.doi.org/10.1111/j.1472-765X.2007.02189.x

Mantle, P. G., McHugh, \& K. M. (1993). Nephrotoxic fungi in foods from nephropathy households in Bulgaria. Mycological Research, 97, 205-212.

http://dx.doi.org/10.1016/S0953-7562(09)80242-6

Maravalhas, M. (1966). Mycological deterioration of cocoa beans during fermentation and storage in Bahia. Int.Chocolate Review, 21, 375-378.

Mounjouenpou, P., Gueule, D., Guyot, B., Tondje, P. R., Fontana-Tachon, A., \& Guiraud, J. P, (2008). Moulds producing ochratoxin A during cocoa processing in Cameroon. International Journal of Food Microbiology, 121, 234 - 241.

http://dx.doi.org/10.1016/j.ijfoodmicro.2007.11.017

Mounjouenpou, P., Gueule, D., Ntoupka, M., Durand, N., Fontana-Tachon, A., Guyot, B., \& Pierre Guiraud, J. P., (2011). Influence of post-harvest processing on ochratoxin A (OTA) content in cocoa and on consumer exposure in Cameroon, World Mycotoxin Journal, 2, 141-146. http://dx.doi.org/10.3920/WMJ2010.1255

Nakajima, M., Tsubouchi, H., Miyabe, M., \& Ueno, Y. (1997). Survey of aflatoxin B1 and Ochratoxin A in commercial green coffee beans by high- performance liquid chromatography linked with immunoaffinity chromatography. Food and Agri. Immunology, 9, 77-83.

http://dx.doi.org/10.1080/09540109709354938

O'Callaghan, J., Caddick, M. X., \& Dobson, D. W. (2003). A polyketide synthase gene required for Ochratoxin A biosynthesis in Aspergillus ochraceus. Microbiology, 149, 3485-3491. http://dx.doi.org/10.1099/mic.0.26619-0

Pitt J. I., Basilico J. C., Abarca M. L., \& Lopez C. (2000). Mycotoxins and toxinogenic fungi. 
Medical Mycology, 38, 41-46.

Pittet, A., Tounare, D., Huggett, A., \& Viani, R., (1996). Liquid chromatographic determination of ochratoxin A in pure and adulterated soluble coffee using an immunoaffinity column cleanup procedure. J. of agri. and food chemistry, 44, 3564-3569.

http://dx.doi.org/10.1021/jf9602939

Romero, S. M., Patriarca, A., Ferna'ndez-Pinto, V., \& Vaamonde, G. (2007). Effect of water activity and temperature on growth of ochratoxigenic strains of Aspergillus carbonarius isolated from Argentinean dried vine fruits. Int J Food Microbiol, 115, 140-143.

http://dx.doi.org/10.1016/j.ijfoodmicro.2006.10.014

Sage, L., Krivobok, S., Delbos, E., Seigle-Murandi, F., \& Creppy, E. E. (2002). Fungal flora and ochratoxin A production in grapes and musts from France. J Agric Food Chem, 50, 1306-1311. http://dx.doi.org/10.1021/jf011015z

Samson, R. A., Hoekstra, E. S., Frisvad, J. C., \& Filtenborg, O. (1995). Introduction to food-borne fungi. Centraalbureau voor Schimmelcultures, Baarn, Delft Netherlands $7^{\text {th }}$ edition.

Skaug, M. A. (1999). Analysis of Norwegian milk and infant formulas for Ochratoxin A. Food Add. and Conta., 16, 75-78. http://dx.doi.org/10.1080/026520399284235

Suàrez-Quiroz, M., Gonzàlez-Rios, O., Barel, M., Guyot, B., Schorr-Galindo, S., Guiraud, \& J. P. (2004). Study of Ochratoxin A-producing strains in coffee processing. Journal of Food Science and Technology, 39, 501-507.

Suàrez-Quiroz, M., Gonzàlez-Rios, O., Barel, M., Guyot, B., Schorr-Galindo, S., \& Guiraud, J. P. (2005). Effect of post-harvest processing procedure on OTA occurrence in artificially contaminated coffee. International Journal of Food Microbiology, 103, 339-345.

http://dx.doi.org/10.1016/j.ijfoodmicro.2004.11.044

Taniwaki, M. H., Pitt, J. I., Urbano, G. R., Teixeira, A. A., \& Leita o, M. F. F. (1999). Fungi producing OTA in coffee. $18^{\text {th }}$ Int Scient Coll Coffee, Helsinki, pp. 239-247.

Taniwaki, M. H., Pitt, J. I., Texeira, \& Iamanaka B. T. (2003). The source of ochratoxin A in Brazilian coffee and its formation in relation to processing methods. International J. of Food Microbiol., 82, 173-179. http://dx.doi.org/10.1016/S0168-1605(02)00310-0

Thirumala-Devi, K., Mayo, M. A., Reddy, G., Emmanuel, K.E., Larondelle, Y., \& Reddy, D. V. R., (2001). Occurrence of Ochratoxin A in black pepper, coriander, ginger and turmeric in India. Food Add. and Conta., 18, 830-835.

Tournas, V., Stack, M. E., Mislivec, P.V., Koch, H. A., \& Bandler, R. (2001). Bacteriological Analytical Manual Online. US Food \& Drug Administration (http//www.cfsan.fda.gov/ ebam/bam-18.html).

WHO (World Health Organization). (1996). Evaluation of certain food additives and 


\section{Macrothink}

contaminants. $44^{\text {th }}$ Report of JECFA; WHO Technical Report series 859; WHO: Geneva, Switzerland.

\section{Copyright Disclaimer}

Copyright reserved by the author(s).

This article is an open-access article distributed under the terms and conditions of the Creative Commons Attribution license (http://creativecommons.org/licenses/by/3.0/). 